\title{
Application of the Correlation Measurement Method for Reconstructing of the Velocity Profile with Spatial and Temporal Discretization in Studies of the Hydrodynamics of Turbulent Flows Based on the Matrix Conductometry Method
}

\author{
S.M. Dmitriev ${ }^{1}$, A.E. Khrobostov ${ }^{1}$, D.N. Solncev ${ }^{1}$, A.A. Barinov ${ }^{2}$, A.A. Chesnokov ${ }^{2}$,
} I.A. Konovalov ${ }^{2}$, M.A. Makarov ${ }^{1}$, T.K. Zyryanova ${ }^{1}$

${ }^{l}$ Nizhny Novgorod State Technical Univercity n.a. R.E. Alekseev, Minin str., 24, Nizhny Novgorod 603950, Russia

${ }^{2}$ Joint Stock Company "Afrikantov OKB Mechanical Engineering", Burnakovsky proyezd, 15, Nizhny Novgorod 603074, Russia

Received 19.10.2021

Accepted for publication 01.12.2021

\section{Abstract}

The correlation method for measuring of the coolant flow rate is used in the operation of nuclear power plants and is widespread in research practice including study of turbulent flows hydrodynamics. However the question of its applicability and possibilities in studies using the matrix conductometry method remains open. Earlier the algorithm for determining of the correlation flow rate using a conductometric measuring system was highlighted and the error of the results obtained was estimated and the dependence of the influence of noise and the time of data collection on the reliability of results was investigated. These works were carried out using two independent mesh sensors and the issue of the resolution of local velocity components was not covered. The purpose of this work was to test the correlation method for measuring velocity with temporal and spatial sampling using two-layer mesh conductometric sensors.

As the result velocity cartograms were obtained over the cross-section of the experimental model with quasi-stationary mixing and the value of the average flow rate is in good agreement with the values obtained from the standard flow meters of the stand. Also measurements were carried out at a non-stationary setting of the experiment and realizations of the flow rate and velocity components of the flow at the measuring points were obtained.

Analysis of the obtained values allows to conclude about the optimal data collection time for correlation measurements, as well as the reliability of results.

Keywords: correlation flow meter, spatial and temporal discretization, spatial conductometry, emergency processes in a nuclear power plant.

DOI: $10.21122 / 2220-9506-2021-12-4-292-300$

\begin{tabular}{ll}
\hline Адрес для переписки: & Address for correspondence: \\
Коновалов И.А. & Konovalov I.A. \\
Нижегородский государственный технический университет, & Nizhny Novgorod State Technical Univercity, \\
ул. Минина, 24, г. Нижний Новгород 603950, Россия & $\begin{array}{l}\text { Minin str., 24, Nizhny Novgorod 603950, Russia } \\
\text { e-mail: iliakonowaloff@yandex.ru }\end{array}$ \\
e-таil: iliakonowaloff@yandex.ru & For citation: \\
Для цитирования: & S.M. Dmitriev, A.E. Khrobostov, D.N. Solncev, A.A. Barinov, \\
S.M. Dmitriev, A.E. Khrobostov, D.N. Solncev, A.A. Barinov, & A.A. Chesnokov, I.A. Konovalov, M.A. Makarov, T.K. Zyryanova. \\
A.A. Chesnokov, I.A. Konovalov, M.A. Makarov, T.K. Zyryanova. & Application of the Correlation Measurement Method for Reconstructing \\
Application of the Correlation Measurement Method for Reconstructing & of the Velocity Profile with Spatial and Temporal Discretization \\
of the Velocity Profile with Spatial and Temporal Discretization & in Studies of the Hydrodynamics of Turbulent Flows Based \\
in Studies of the Hydrodynamics of Turbulent Flows Based & on the Matrix Conductometry Method. \\
on the Matrix Conductometry Method. & Devices and Methods of Measurements. \\
Приборы и методы измерений. & 2021, vol. 12, no. 4, pp. 292-300. \\
2021. - Т. 12, № 4.-C. 292-300. & DOI: 10.21122/2220-9506-2021-12-4-292-300 \\
DОI: 10.21122/2220-9506-2021-12-4-292-300 &
\end{tabular}




\title{
Применение корреляционного метода измерений
}

\section{для восстановления профиля скорости}

с пространственной и временной дискретизацией

при исследованиях гидродинамики турбулентных

\section{потоков на базе метода матричной кондуктометрии}

\author{
С.М. Дмитриев ${ }^{1}$, А.Е. Хробостов ${ }^{1}$, Д.Н. Солнцев ${ }^{1}$, А.А. Баринов ${ }^{2}$, А.А. Чесноков ${ }^{2}$, \\ И.А. Коновалов ${ }^{2}$, М.А. Макаров ${ }^{1}$, Т.К. Зырянова ${ }^{1}$
}

${ }^{1}$ Нижегородский государственный технический университет имени Р.Е. Алексеева, ул. Минина, 24, г. Нижний Новгород 603950, Россия

${ }^{2}$ АО «ОКБМ Африкантов»,

Бурнаковский проезд, 15, г. Нижний Новгород 603074, Россия

Поступила 19.10.2021

Принята к печати 01.12.2021

Корреляционный метод измерения расхода теплоносителя применяется при эксплуатации ядерных энергетических установок и широко распространен в исследовательской практике, в том числе, для изучения гидродинамики турбулентных потоков. Однако вопрос о его применимости и возможностях при исследованиях с использованием метода матричной кондуктометрии остается открытым. В ранее проведенных работах был освещён алгоритм определения корреляционного расхода с использованием кондуктометрической измерительной системы и оценена погрешность полученных результатов, а также была исследована зависимость влияния шума и времени сбора данных на достоверность полученных результатов. Однако, данные работы были проведены с использованием двух независимых сетчатых датчиков и вопрос о разрешении локальных скоростных компонент не был освещён. В связи с этим целью данной работы являлось проведение апробации корреляционного метода измерения скорости с временной и пространственной дискретизацией с использованием двухслойных сетчатых кондуктометрических датчиков.

Получены картограммы скорости по сечению экспериментальной модели при квазистационарном смешении, а значение среднерасходной скорости хорошо согласуется со значениями, полученными со штатных расходомеров стенда. Проведены измерения при нестационарной постановке эксперимента и получены реализации расхода и скоростных компонент потока в измерительных точках.

Анализ полученных значений позволяет сделать вывод об оптимальном времени сбора данных при корреляционных измерениях, а также о достоверности полученных результатов.

Ключевые слова: корреляционный расходомер, пространственная и временная дискретизация, пространственная кондуктометрия, аварийные процессы в ЯЭУ.

DOI: $10.21122 / 2220-9506-2021-12-4-292-300$

\begin{tabular}{|c|c|}
\hline Адрес для переписки: & Address for correspondence: \\
\hline Коновалов И.А. & Konovalov I.A. \\
\hline Нижегородский государственный технический университет, & Nizhny Novgorod State Technical Univercity, \\
\hline ул. Минина, 24, г. Нижний Новгород 603950, Россия & Minin str., 24, Nizhny Novgorod 603950, Russia \\
\hline e-mail: iliakonowaloff@yandex.ru & e-mail: iliakonowaloff@yandex.ru \\
\hline Для цитирования: & For citation: \\
\hline S.M. Dmitriev, A.E. Khrobostov, D.N. Solncev, A.A. Barinov, & S.M. Dmitriev, A.E. Khrobostov, D.N. Solncev, A.A. Barinov, \\
\hline A.A. Chesnokov, I.A. Konovalov, M.A. Makarov, T.K. Zyryanova. & A.A. Chesnokov, I.A. Konovalov, M.A. Makarov, T.K. Zyryanova. \\
\hline Application of the Correlation Measurement Method for Reconstructing & Application of the Correlation Measurement Method for Reconstructing \\
\hline of the Velocity Profile with Spatial and Temporal Discretization & of the Velocity Profile with Spatial and Temporal Discretization \\
\hline in Studies of the Hydrodynamics of Turbulent Flows Based & in Studies of the Hydrodynamics of Turbulent Flows Based \\
\hline on the Matrix Conductometry Method. & on the Matrix Conductometry Method. \\
\hline Приборы и методы измерений. & Devices and Methods of Measurements. \\
\hline 2021. - T. 12, № 4. - С. 292-300. & 2021, vol. 12 , no. 4 , pp. $292-300$ \\
\hline DOI: $10.21122 / 2220-9506-2021-12-4-292-300$ & DOI: $10.21122 / 2220-9506-2021-12-4-292-300$ \\
\hline
\end{tabular}




\section{Introduction}

In the course of developing new designs of reactor plants work is underway to solve the problems of increasing the reliability, safety and efficiency of operation of power units which requires computational and experimental studies. One of the problem of substantiating the safety of a power unit is the computational modeling of thermohydraulic processes under emergency operating conditions which are distinguished by the unsteady of the ongoing processes [1-2]. Justification of the applicability of the computational models used requires validation experiments which, in turn, raises the question of developing new systems for monitoring and recording local flow characteristics with spatial and temporal sampling. One of these characteristics is the value of the coolant flow rate.

At the moment the correlation method for measuring of the coolant flow rate is widely known the main requirement of which is the presence in the flow of some passive scalar function (tracer), convectively transferred together with the medium. It allows one to implement correlation measurements using various methods for measuring of flow properties: temperature, content of radioactive isotopes, optically distinguishable impurities, etc. [3-4]. This approach assumes determination of the transit time of the disturbance of the measured quantity (the so-called turbulence transport time) between the sensitive elements of the system which are located at some distance from each other.

The algorithm for the correlation determination of the flow velocity using a conductometric measuring system, considered and tested in [5] based on calculating the position of the maximum of the cross-correlation function (CCF) corresponding to the time of turbulence transport between the sensors showed a small relative error which allows to speak about the applicability of this method in experimental studies using a conductometric measuring system. In previous studies it was concluded that the contribution of noise to the error in determining the maximum CCF which was calculated in accordance with the method proposed in [6] was concluded. In addition, a study of dependence of the variance of readings on the time of data collection showed that a good accuracy in determining the maximum
$\mathrm{CCF}$ is maintained when the data collection time is reduced down to 1 second.

The purpose of this work was to test the correlation measurement method for reconstructing the flow velocity field with spatial and temporal sampling based on the matrix conductometry method using a two-layer mesh sensor design.

\section{Test facility}

The general scheme of the test facility (Figure 1) assumes the organization of an experimental mode with isothermal mixing in an open circulation loop (for studies using flows with different concentrations of impurities) and non-isothermal mixing when using flows with different temperatures.

The equipment of the test facility makes it possible to create laminar, transient and turbulent flows (at Reynolds numbers Re up to $20 \cdot 10^{3}$ ) at different temperatures, flow rates and impurity concentrations in mixing coolant flows. The main parameters of the test facility are presented in Table 1.

Table 1

The main parameters of the experimental stand

\begin{tabular}{lc}
\hline Parameter & Value \\
\hline The total power of the heaters, $\mathrm{kW}$ & 12 \\
Flow through test model, $\mathrm{m}^{3} / \mathrm{hr}$ & Up to 2.1 \\
Temperature of the mixing flows, ${ }^{\circ} \mathrm{C}$ & $10-60$ \\
\hline
\end{tabular}

\section{Measurement system}

In experimental studies, a measuring system, consisting of an electrical impedance measuring system LAD-36 and a two-layer wire mesh sensor (WMS) [7-10] was used. The general view of the system is shown in Figure 2.

A distinctive feature of a two-layer WMS in comparison with a single-layer WMS is the use of two layers of receivers located symmetrically relative to the layer of generators (Figure 3).

This feature makes it possible to implement two measuring planes in one WMS housing and to minimize the distance between the measuring sections. The measuring planes are formed by a set of measuring cells formed by the imaginary intersection of the electrodes of the receiver layer and the generator layer. 


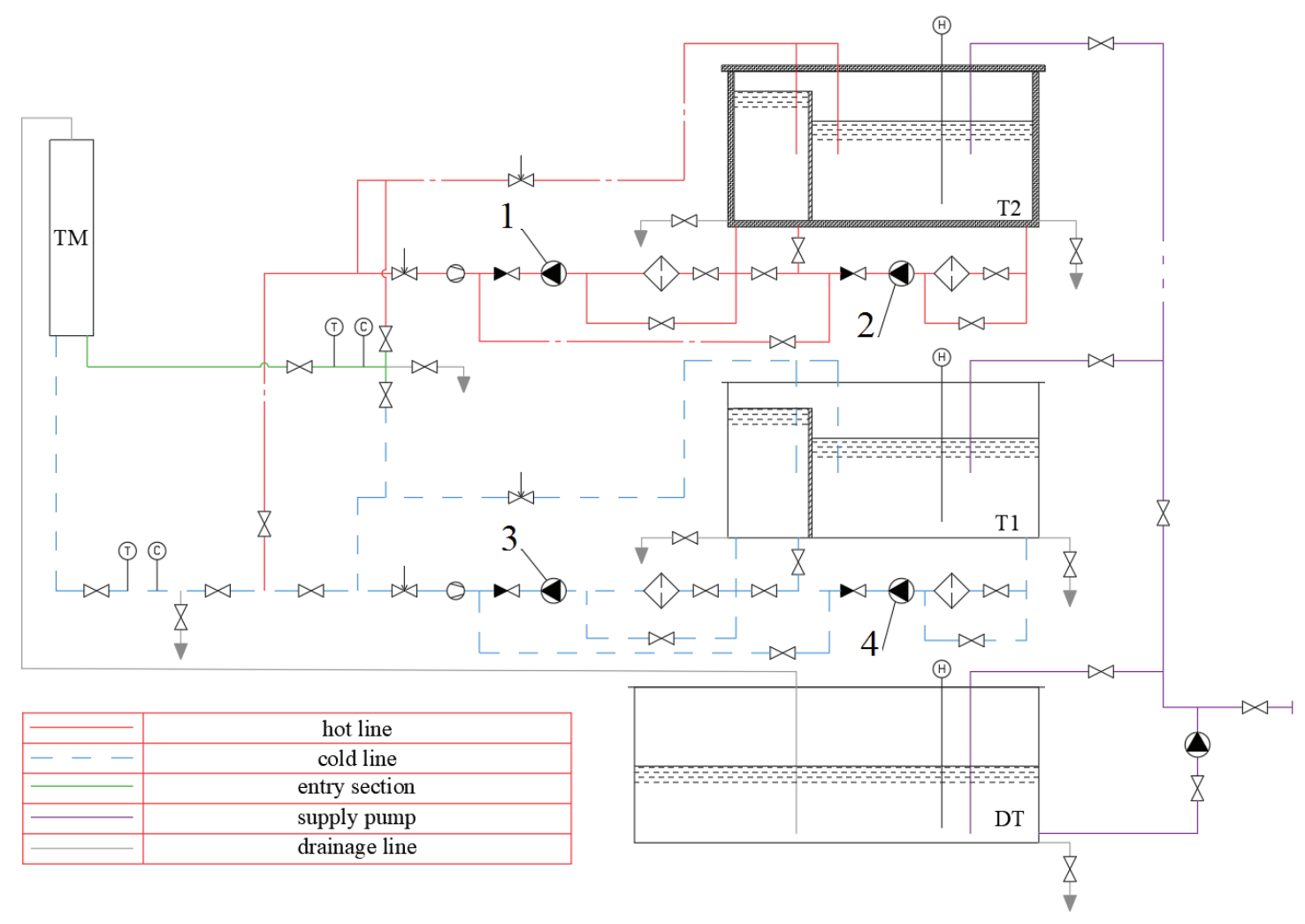

Figure 1 - Hydraulic diagram of the test facility: 1 - hot line circulation pump; 2 -make-up for us hotline; 3 - cold line circulation pump; 4 - make-up pump of the cold line; T1 - cold feed tank; T2 - hot feed tank; DT - drainage tank; TM - test model

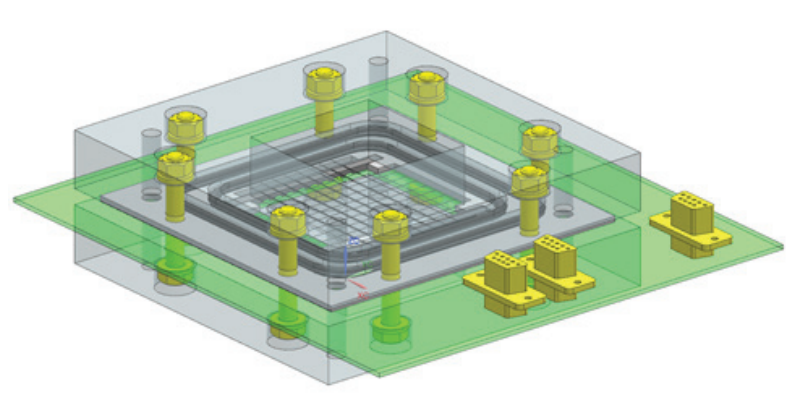

Figure 2-General view of a two-layer conductometric sensor

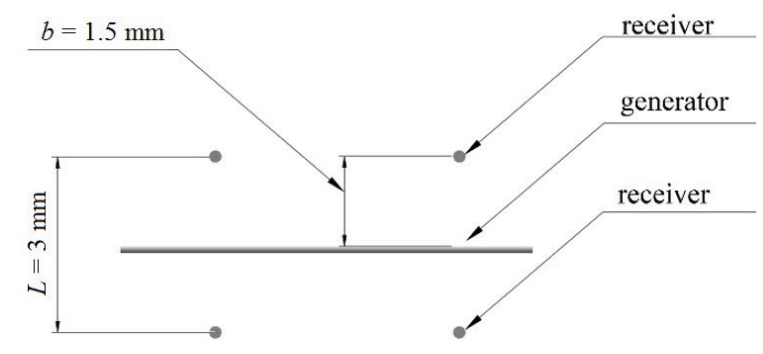

Figure 3 - Scheme of the mutual arrangement of the electrodes of a two-layer sensor

\section{Experimental setup}

The measurements were carried out in an experimental model with a square cross section of $50 \times 50 \mathrm{~mm}$, the general view of which is shown in Figure 4. The WMS was installed in the zone of intensive mixing at $650 \mathrm{~mm}$ from the edge of the dividing wall.

The matrix of experimental regimes included developed turbulent flows with flow rates ranging from $1.0 \mathrm{~m}^{3} / \mathrm{h} \quad\left(\operatorname{Re}=10 \cdot 10^{3}\right)$ to $2.1 \mathrm{~m}^{3} / \mathrm{h}$ $\left(\operatorname{Re}=19 \cdot 10^{3}\right)$ in a steady and unsteady setting (with a change in flow rate during the experiment). The actual flow rate was recorded using high-precision flow meters for each of which an individual calibration was carried out.

The study of the influence of the time discretization of the measuring signal on the obtained readings was carried out by dividing the initial signal into a given number of time intervals, for each of which the position of the maximum of the correlation function of specific electrical conductivity $X(t)$ and $Y(t)$ determined in the measuring cells of a two-layer mesh sensor. In accordance with the methodology described 
in [4], the discrete CCF of time sequences $X(t)$ and $Y(t)$ was calculated according to (1), and the average flow rate was determined using a weight factor that takes into account the position of the measuring cell and the correlation coefficient of the conductivity:

$$
R_{k}(X, Y)=\frac{1}{\sqrt{R_{x x}(0) R_{y y}(0)}} \cdot \frac{1}{N} \sum_{t=0}^{N-1} x_{t} \cdot y_{t},
$$

where $\frac{1}{\sqrt{R_{x x}(0) R_{y y}(0)}}$ is CCF normalization parameter; $x_{t}$ is conductivity received from the first layer of WMS; $y_{t}$ is conductivity received from the second layer of WMS; $N$ is the number of time samples in the realization.

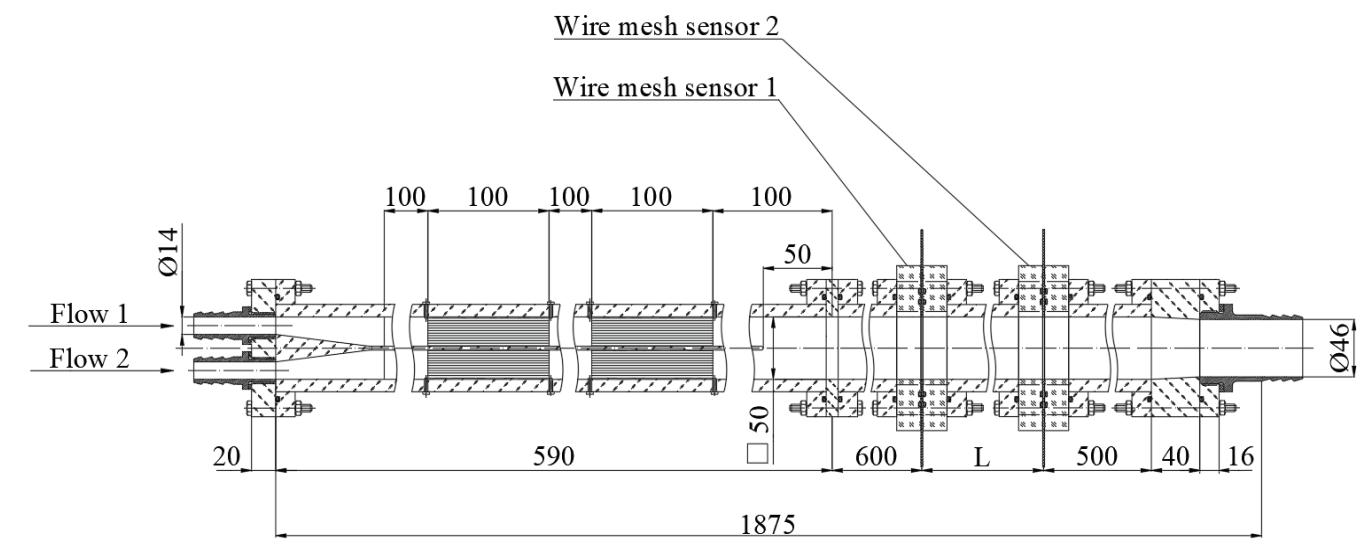

Figure 4 - Test model

As a result of the analysis of the experimental data, the realizations of the values of the velocity components of the flow at the measuring points were obtained formed by a pair of measuring cells of the first and second layers of the WMS which are located in accordance with the accepted numbering of the cells shown in Figure 5.

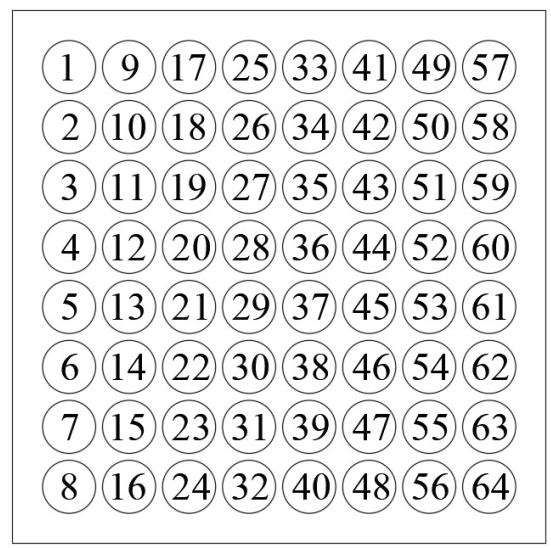

Figure 5 - Measuring cells of the wire mesh sensor

\section{Measurement results}

As a result of the measurements, the instantaneous values of the conductivity were obtained in the measuring cells of the sensor from which the $\mathrm{CCF}$ was calculated. Figure 6 shows an example of realizations of the conductivity of the first and second measuring cross sections and their CCF for a stationary flow regime with $\operatorname{Re}=18 \cdot 10^{3}$.

The conductivity implementations practically coincide in their appearance with a relatively smalltime shift, which indicates the predominant preservation of the flow structure along the path between the measuring sections and is confirmed by a high level of correlation of readings.

Table 2 shows the values of the flow rate and velocity in the experimental model obtained by the correlation method in comparison with the values of standard flow meters.

The obtained relative error decreases with an increase in the Reynolds number, and its small value allows us to speak about the possibility of using the correlation method for measuring the velocity when using a two-layer WMS with a relatively small distance between the measuring sections, to restore the velocity field in the cross section of the experimental model.

The resulting velocity cartograms in the cross-section of the experimental model are shown in Figure 7.

The presented figures indicate that the spatial values of the velocities obtained in this way reflect the presence of an irregularity of the profile in the cross section of the model, and the nature of the irregularity is consistent with the shape of the velocity profile at a steady turbulent flow regime with a formed flow core. 

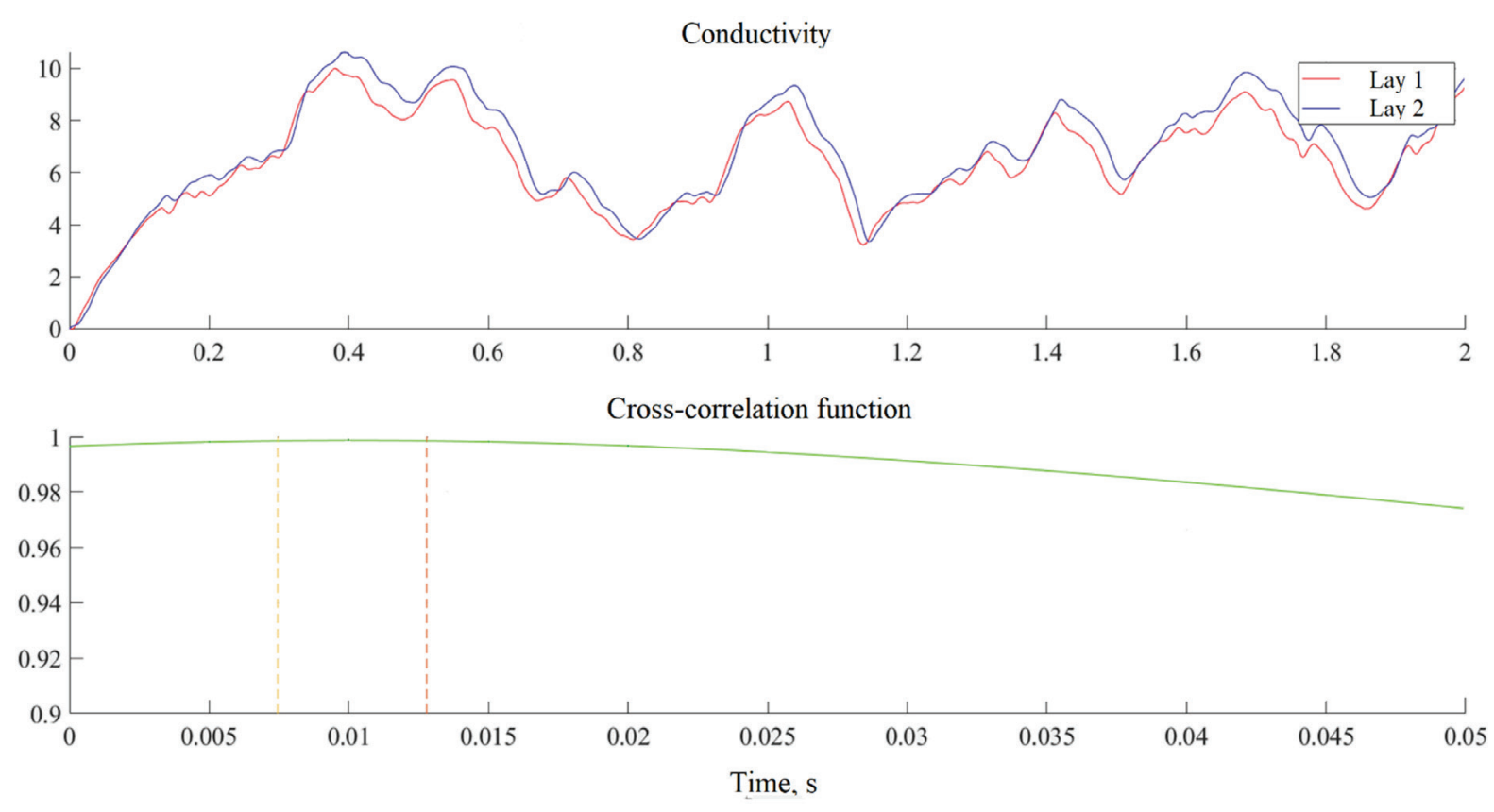

Figure 6 - An example of realizations of conductivity and their cross-correlation function for the mode $\operatorname{Re}=18 \cdot 10^{3}$

Table 2

\section{Comparative analysis of values}

$\operatorname{Re} \cdot 10^{3}$

Parameter

10

15

18

Consumption according to readings of standard flow meters, $1 / \mathrm{min}$

17.26

25.76

32.43

32.62

Average flow rate according to readings of standard flow meters, $\mathrm{m} / \mathrm{s}$

0.115

0.172

0.216

0.218

Correlation flow rate, $1 / \mathrm{min}$

18.60

25.90

33.00

33.6

Correlation average flow rate, $\mathrm{m} / \mathrm{s}$

0.124

0.185

0.227

0.224

Relative speed error, $\%$

7.8

7.5

5.1

When setting an unsteady mixing mode, the flow rate through the experimental model was changed by adjusting the shut-off valves installed at the outlet of the experimental model. The realizations of the flow rates of the mixing flows and the average flow rate in the model according to the readings of standard flow meters are shown in Figure 8.

As a result of the oversampling of the original implementation and further calculation of the CCF by the windows, realizations of the velocity components of the flow were obtained, which were used to determine the correlation flow rate through the experimental model. The correlation flow rate depending on the sampling period in comparison with the total flow rate obtained from standard flow meters is shown in Figure 9.

As can be seen from the presented dependences, with an increase in the sampling frequency (a decrease in the data collection time), errors arise in determining the flow rate by the correlation method, and with a decrease, the implementation is smoothed, which leads to the exclusion of high-frequency ripples from the implementation. Based on the foregoing, the optimal polling period for correlation measurements on this WMS design is 2 seconds. 


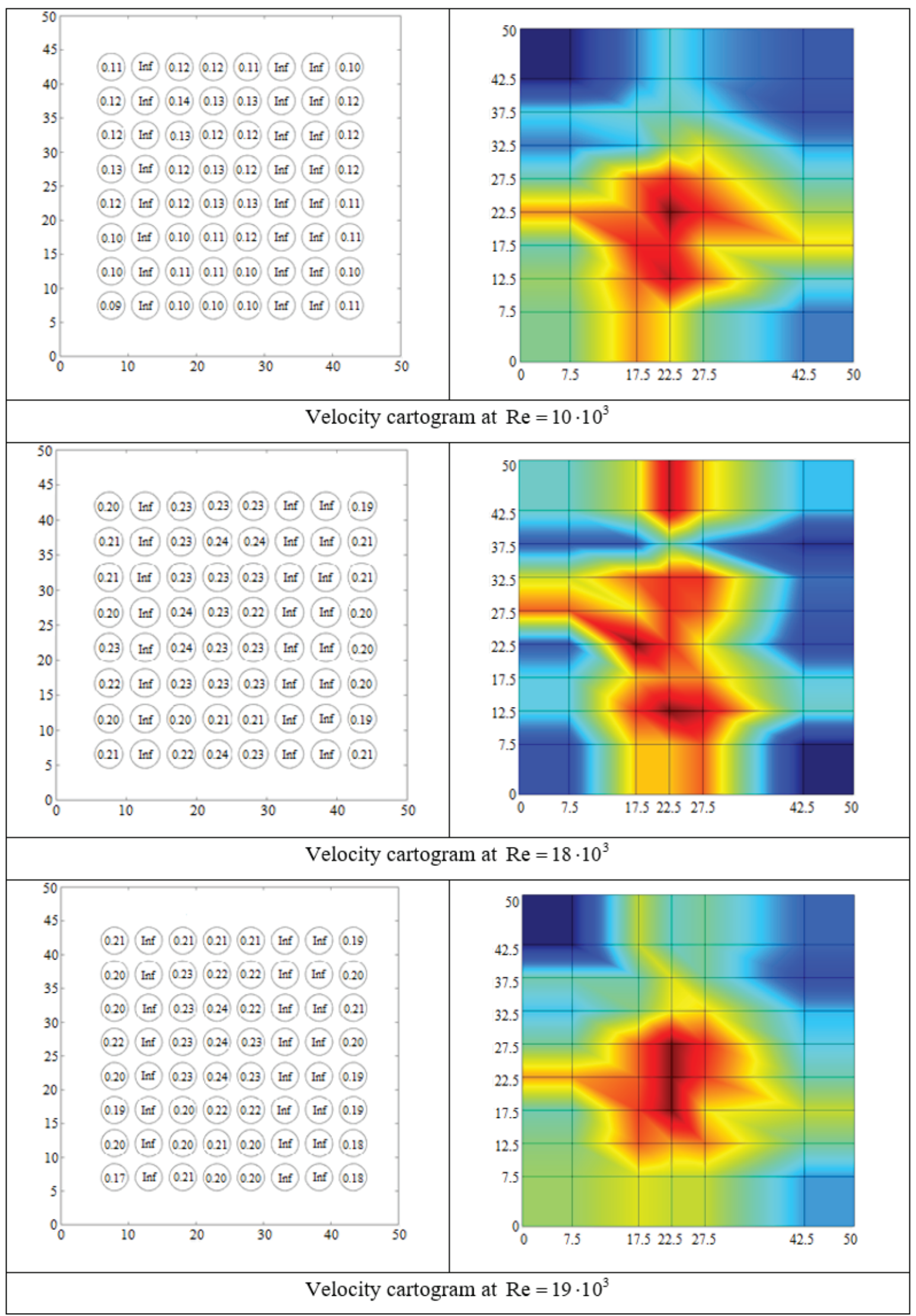

Figure 7 - Cartograms of velocity depending on the flow regime 

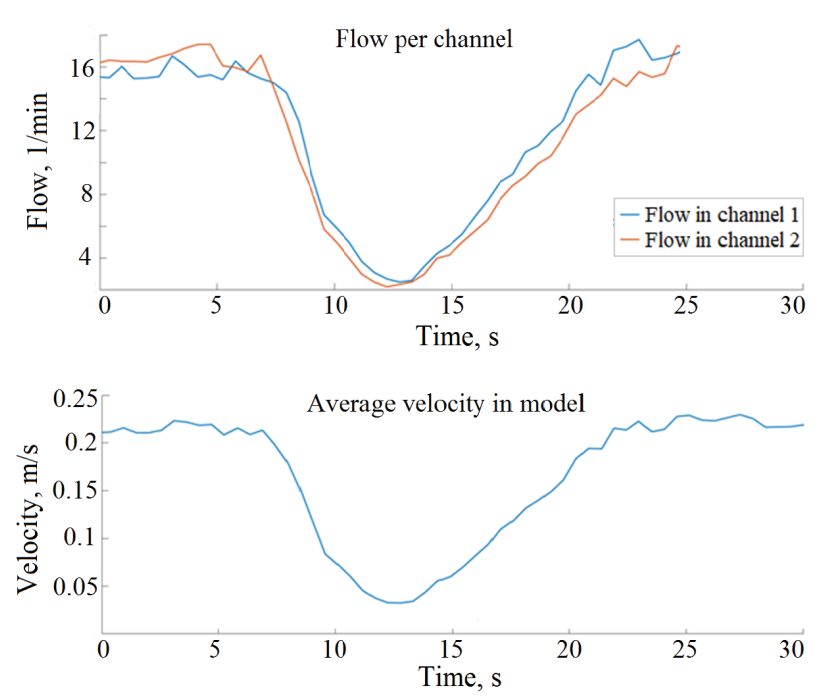

Figure 8 - Realization of flow rates and average flow according to the readings of standard flow meters

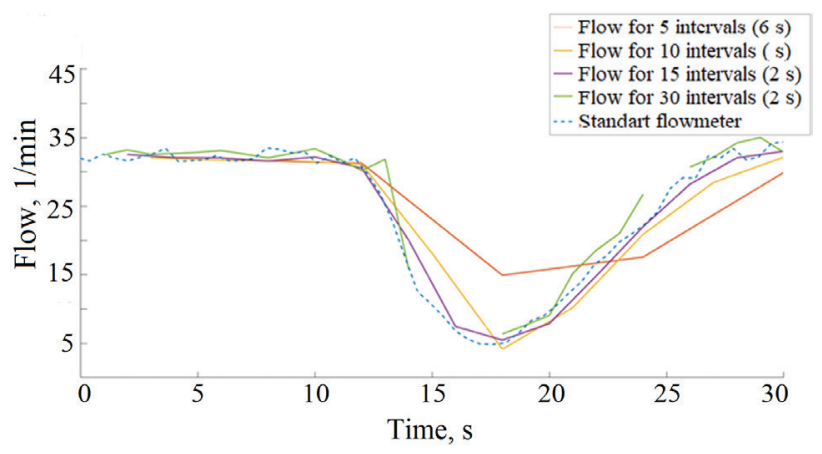

Figure 9 - Comparative chart of expenses

Realizations of the correlation velocity at measuring points 33, 36 and 40, which are located at the periphery and in the centre of the model section, with a sampling period of two seconds are shown in Figure 10.

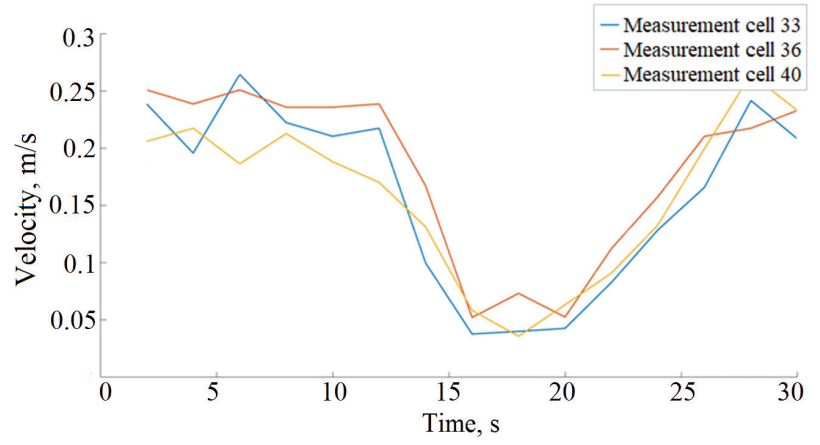

Figure 10 - Realization of velocity at the peripheral and central measuring point of the model section

It can be seen from these realizations that the correlation values of the velocity correctly describe the shape of the velocity profile and its change, with the exception of periodic deviations caused by errors in determining the maximum CCF.

\section{Conclusion}

The correlation measurements of velocity carried out in this work using the method of matrix conductometry demonstrated a small relative error when using a two-layer wiremesh sensor which allows to speak of the reliability of the results obtained and the shape of the velocity profiles in the cross section of the model.

Measurements carried out using oversampling of the original implementation made it possible to obtain high-speed realizations and realizations of the flow rate depending on the time of data collection. These implementations in comparison with the implementation of the flow rate from standard flow meters allow to speak about the possibility of using this measurement method when studying the pulsation components of the flow. However, there are limitations in the sampling period which are associated with the impossibility of calculating the cross-correlation function with a short data acquisition time (with this sensor design, the minimum sampling period is two seconds).

Also, this measurement method can be used in the study of non-stationary processes in models of nuclear power plants which is necessary to substantiate safety in emergency modes of operation.

\section{Acknowledgments}

The work was carried out within the framework of the state assignment in the field of scientific activity (topic No. FSWE-2021-0008).

\section{References}

1. Mazurok A.S., Alekseev Y.P. [Analysis of Methods for Modeling Local Thermohydraulic Processes in Elements NPP]. Teplovi ta yaderni energetichni ustanovki [Thermal and Nuclear Power Units], 2013, no. 3, pp. $23-$ 34 (in Ukrainian).

2. Vorobjov Y.Y., Kocheryanc O.R. [Thermal-hydraulic model of VVER-1000 reactor to obtain the boundary conditions for destruction resistance estimation with application RELAP5/MOD3.2]. Jadernaja i radiacionnaja bezopasnost' [Nuclear and radiation safety], 2011, no. 50, pp. 13-19 (in Russian).

3. Velt I.D., Mikhailova J.V., Sudakov V.K. [Measurements of Liquid Metal Coolant Flow in The Breeder 
Reactors]. Izmeritelnaya tehnika [Measuring Technology], 2018, no. 1, pp. 22-27 (in Russian).

DOI: $10.32446 / 0368-1025$ it.2018-1-22-27

4. Por G., Berta M., Csuvar M. Measurement of the Coolant Flow Rate using Correlation of Temperature Fluctuations. Progress in Nuclear Energy, 2003, no. 14, pp. 281-288. DOI: 10.1016/S0149-1970(03)00038-6

5. Konovalov I.A., Khrobostov A.E., Legchanov M.A., Solncev D.N., Barinov A.A., Ryazanov A.V., Chesnokov A.A., Makarov M.A. Application of the Correlation Velocity Measurements for Hydrodynamic Investigations of Turbulent Coolant Flow in Nuclear Reactor Elements. Devices and Methods of Measurements, 2020, no. 3, pp. 196-20 (in Russian).

DOI: $10.21122 / 2220-9506-2020-11-3-196-203$

6. Bendat J., Piersol A. Random Data: Analysis and Measurements Procedures. Fourth Edition. John Willey \& Sons, 2012, pp. 272-274.

7. Barinov A.A., Varencov A.A., Glavny V.G., Dmitriev S.M., Legchanov M.A., Ryazanov A.V., Khro- bostov A.E. [Implementation of The Method of Spatial Conductometry for Experimental Research of The Processes od Mixing Intra-reactor Flows in Moder Nuclear Units]. Trudy NGTU im. R.E. Alekseeva [Transactions of NNSTU n.a. R.E. Alekseev], 2017, no. 2, pp. 35-41 (in Russian).

8. Prasser H.M., Kliem S. Coolant mixing experiments in the upper plenum of the ROCOM test facility. Nuclear Engineering and Design, 2014, vol. 276, pp. 30 42. DOI: $10.1016 /$ j.nucengdes.2014.05.016

9. Dave A., Manera A., Beyer M., Lucas D., Prasser H.M. Uncertainty analysis of an interfacial area reconstruction algorithm and its application to two group interfacial area transport equation validation. Nuclear Engineering and Design, 2016, vol. 310, pp. 620-637.

DOI: $10.1016 /$ j.nucengdes.2016.10.038

10. Velasco H.F., Rodriguez O.M.H. Applications of wire-mesh sensors in multiphase flows. Flow Measurement and Instrumentation, 2015, vol. 45, pp. 255-273.

DOI: $10.1016 /$ j.flowmeasinst.2015.06.0240955-5986 